\title{
The De anima Tradition in Early Franciscan Thought
}

\section{A Case Study in Avicenna's Reception}

\begin{abstract}
In the $12^{\text {th }}$ and early $13^{\text {th }}$ centuries, we witness a steady rise in the level of sophistication with which scholars analysed the nature of the rational soul. This increase was undoubtedly attributable to the translation movement of the period, which made many Greek and Arabic philosophical texts available in Latin for the first time. This paper will show how the introduction of Avicenna's De anima in particular mediated readings of Aristotle as well as Augustine in the period of the Summa's authorship, specifically, as regards the account of the soul, its relationship to the body, and its cognitive operations. In this way, I will illuminate the extent to which the reading of Avicenna shaped fundamentally the ways in which the Franciscan tradition came to construe human nature.
\end{abstract}

Throughout history, the soul has remained a topic of perennial interest and debate. In the $12^{\text {th }}$ and early $13^{\text {th }}$ centuries, we witness a steady rise in the level of sophistication with which scholars analysed the nature of the rational soul. This increase was undoubtedly attributable to the translation movement of the period, which made many Greek and Arabic philosophical texts available in Latin for the first time. The most significant of these texts were the works of Aristotle and the Islamic philosopher Avicenna, who dominated the reception of Aristotle until nearly the mid $13^{\text {th }}$ century. At this point, better translations of Aristotle were produced which enabled the study of his thought in its own right.

The reasons for the focus on Avicenna over or with Aristotle until this time are many, but among them, there is the fact that the translations of Aristotle that were produced in the mid-to-late $12^{\text {th }}$ century were in some cases only partial and in most cases, riddled with inaccuracies. For this reason, Latin thinkers were more inclined to rely on the superior and more complete translations of Avicenna, who was in fact a very different thinker to Aristotle with a system and views all his own. Although Avicenna was clearly the main resource for reading Aristotle before, say, the 1250s and 60s, his own reception was mediated and mitigated by numerous other figures, such as Dominicus Gundissalinus, the translator of Avicenna, as well as the Spanish Jew Avicebron and the Syrian Christian Costa Ben Luca, whose works were translated by Gundissalinus and John of Spain, respectively.

Furthermore, the reception of Aristotle was complicated by the wide circulation of works like the Neo-Platonic Liber de causis which was believed before 1268 to offer a genuine representation of Aristotle's theological views; and by the so-called De spi- 
ritu et anima, a $12^{\text {th }}$-century work that was attributed to Augustine despite evidence to the contrary. These works generated widespread confusion about what Aristotle and Augustine really said, slanting readings of them in favour of Avicenna. What I would like to do in this paper is to give a window into the complex reception of Avicenna in this period by looking at how he was interpreted by some of those who appropriated his work most extensively and enthusiastically, especially in dealing with questions about the soul.

The thinkers I have in mind are the founders of the Franciscan intellectual tradition, who worked together between 1236 and 1245 to author one of the first great theological Summae of a period that became famous for its vast intellectual syntheses. In particular, I refer to John of La Rochelle, whose works on the soul, in particular, his Summa de anima $(S D A ; 1235-6)$ formed the basis for the section on the rational soul in the Summa Halensis. ${ }^{1}$ These works by John were the first sustained effort to take advantage of the new material on natural philosophy that scholars in Paris had been banned from lecturing and publishing upon until around 1231. The only earlier attempt of a similar nature was the De anima of John Blund, who was the first university master of arts to write a treatise on the soul, and who managed to do so just before the first condemnation of Aristotle came into effect in 1210.

In the years between Blund and Rochelle, the topic of the soul was obviously not neglected, nor were the Greco-Arabic sources. Nevertheless, theologians approached the topic in a way that was clearly circumscribed by what might be described as their theological or indeed 'Augustinian inheritance'. Although they dealt with newer questions, for instance, about the body-soul relationship, so far as they felt Augustine's works spurious or otherwise justified it, they did not explore 'nitty gritty' questions about the mechanics of sensation and cognition which are only treated before John by Blund and a couple anonymous authors, and then in a very cursory way that was not entirely faithful to Avicenna's original.

The analysis of such topics that John of La Rochelle gives in his Summa de anima later formed the basis for a section on the rational soul in the Summa Halensis, which thus became the first theological Summa to deal with the cognitive mechanisms that lay beyond the scope of authors like Augustine and John of Damascus, who otherwise loom large in Rochelle's account. Although the Summa de anima and De anima rationali $(D A R)$ section of the Summa Halensis follow almost the exact same line of questioning, and the latter repeats much of the material of the former, there are some differences that may reflect differences in dating. While John probably wrote his Summa between 1235 and 1236, in the heyday of Avicenna's Latin reception, the De anima rationali makes a more concerted-though no more informed-effort to interact with Aristotle on some issues. This seems to suggest a possible date

1 John of La Rochelle, Summa de anima, ed. Jacques Guy Bougerol (Paris: Vrin, 1995). See also Rochelle's work dating around 1232, the Tractatus de divisione multiplici potentiarum animae, ed. Pierre Michaud-Quantin (Paris: Vrin, 1964). 
around or after 1240, when the Averroes commentaries on Aristotle were beginning to garner interest and draw more attention towards Aristotle in his own right.

Throughout my discussion, I will refer to both of the aforementioned Franciscan texts, tracing some developments between them. The 'way in' I will invoke for exploring the nature and extent of Avicenna's influence in these works is a list the Summa provides of the basic differences between human souls and angels. While this comparison might seem like an unusual springboard for exploring key aspects of human psychology, David Keck has aptly observed that it was as normal for medievals to take angels as their point of departure for studying human nature as it currently is for modern scientists to compare humans with animals. ${ }^{2}$ The differences in question pertain to what the Summa calls the esse naturale, esse rationale, and esse metaphysico of the rational beings in question.

As Theo Kobusch has shown, this three-fold way of categorizing modes of esse is unique to the Summa Halensis and as we will see, it has far-reaching implications for the doctrines formulated within it. ${ }^{3}$ When it comes to angels and rational souls, the category of esse naturale distinguishes between beings which are either 'separate according to substance' (separatum secundum substantiam) from the body or 'unitable according to substance' (unibile secundum substantiam). ${ }^{4}$ As far as esse rationale or esse logicum is concerned, rational souls differ from angels because they engage in discursive reasoning where angels know simply. Put differently, human beings pursue knowledge and make discoveries while angels 'just know' what is true. ${ }^{5}$ That said, both can be described as images of God in virtue of the rational power. ${ }^{6}$

In terms of esse metaphysicum, angels and rational souls differ in their way of being receptive or in a state of potentiality with respect to knowing the natural world. Although angels are certainly capable of knowing things that are inferior to themselves, they do not receive phantasms or images of things from those things themselves, as if from below. Rather, they receive the forms of things through illumination from above. ${ }^{7}$ As we will discover, human beings also receive forms from above

2 David Keck, Angels and Angelology in the Middle Ages (Oxford: Oxford University Press, 1998), 16. 3 Theo Kobusch, 'The Summa Halensis: Towards a New Concept of Person,' in The Summa Halensis: Doctrines and Debates (Berlin: De Gruyter, 2020).

4 Alexander of Hales, Doctoris irrefragabilis Alexandri de Hales Ordinis minorum Summa theologica (SH), 4 vols (Quaracchi: Collegium S. Bonaventurae, 1924-48), Vol II, In2, Tr2, Q1, C5 (n. 112), Solutio, p. 150.

5 SH II, In2, Tr2, Q1, C5 (n. 112), Solutio, p. 151: 'Dico autem intellectum cum ratione intellectum componentem et dividentem et ab extremo ad extremum per medium decurrentem, quo modo non est in intelligentia angelica: intelligit enim modo simplici sine decursu rationis.'

6 SH II, In2, Tr2, Q1, C5 (n. 112), Ad obiecta 6.b, p. 152: both angels and humans are the image of God by virtue of rational power.

7 SH II, In2, Tr2, Q1, C5 (n. 112), Solutio, p. 151: 'Secundum esse vero metaphysicum differunt essentialiter per intellectum possibilem ad species in phantasmatibus et intellectum abstractum ab hac possibilitate; intelligentia enim angelica habet intellectum abstractum ab hac possibilitate.' 
by illumination, but in a different way. ${ }^{8}$ These forms do not represent the objects of knowledge as they seemingly do for angels, but the means of abstracting species from phantasms. Ultimately, then, the illuminated forms in humans are only triggered as a result of receiving those phantasms from below, after which they can be rendered intelligible through the forms acquired from above.

These distinctions, while not elaborate in their detail, provide a useful basis for examining more closely some of the key areas in which early Franciscans adopted ideas from Avicenna, among other new sources. In what follows, I will take these issues one-by-one, starting with the question of embodiment encapsulated by the mode of esse naturale before turning to the rational soul's cognitive operations as reflected in esse rationale and esse metaphysico. As we have seen, the essential difference between angels and the rational human soul with regard to esse naturale is that 'an angel is a substance separate from the body but the soul is unitable to the body."

Following Avicenna, early Franciscans hold that the soul can be considered in two ways, either in its own right, independently of the body, and in this way, they describe it as a 'spirit'. ${ }^{10}$ Alternatively, it can be considered in relation to the body, and in this sense, it is properly called a soul. ${ }^{11}$ Corresponding to this two-fold account of the soul, the Summa argues that there are two ways to describe something as corporeal, either absolutely, or by reason of some conditions. If we think of the soul absolutely, then the human soul is not corporeal but incorporeal and therefore separate from the body.

To establish this point, the Summa presents a number of arguments. The first, drawn from Avicenna, states that one thing that moves another is distinct from the essence of what it moves; since the soul moves the body, it must therefore be distinct from the essence of the body and is a substance in its own right. ${ }^{12}$ Another argument, which invokes an analogy found in Aristotle's De anima, states that the soul has a body as a sailor a ship; a sailor is divided according to substance from the ship, as he moves the ship and is thereby moved by it accidentally. Therefore, the soul is a substance divided from the body and a substance beyond the body. ${ }^{13}$ In

8 SH II, In2, Tr2, Q1, C5 (n. 112), Ad obiecta 6.a, p. 152: ‘angelus substantia intellectualis, illuminationum, quae sunt a Primo, prima relatione perceptiva, anima vero, ultima relatione perceptiva.'

9 SH II, In2, Tr2, Q1, C5 (n. 112), p. 149: 'angelus est substantia separata a corpore, anima vero est unibilis corpori.'

10 SH II, In4, Tr1, S1, Q1, C2 (n. 321), Respondeo 2, p. 385.

11 Richard C. Dales, The Problem of the Rational Soul in the Thirteenth Century (Leiden: Brill, 1995), 8: 'The human soul may be considered from two points of view: as it is related to the body, and as it is in itself.'

12 SH II, In4, Tr1, S1, Q1, C2 (n. 321), Respondeo 2.a, p. 386a: 'Quod movens per se est distinctum per essentiam a mobili; sed anima movet corpus; ergo est distincta per essentiam a corpore; ergo est substantia praeter substantiam corporis.'

13 SH II, In4, Tr1, S1, Q1, C2 (n. 321), Respondeo 2.b, p. 386, citing Aristotle, De anima 2.1: 'anima se habet ad corpus sicut nauta ad navim; sed nauta secundum substantiam dividitur a navi, cum movet 
his own work, John of La Rochelle establishes the soul as a separable substance through explicit invocation of Avicenna's 'flying man' argument, which notes that a human being deprived of all their senses would still be able to reason and therefore would not be able to doubt the independent existence of the rational soul. ${ }^{14}$

What makes the soul a substance, on the Summa's understanding, is that it is comprised not only of form but also of matter-not physical matter, of course, but a sort of intellectual matter. ${ }^{15}$ This application of the doctrine of universal hylomorphism, or the idea that all substances, including rational souls and angels, are comprised of matter and form, is not actually found in Avicenna but in Avicebron, whose theories were encountered by Latin thinkers largely through the mediation of Gundissalinus. Although the soul so construed is an independent entity, it can also be considered a 'perfection' in relation to the body, or that which animates the body in the first instance.

For Avicenna, the soul has a natural inclination not just to any body but to one in particular. This inclination sets one soul apart from another, establishing the soul rather than the body or matter as the principle of individuation. Although the soul needs the body in order to enact its individuality, that is, to distinguish itself from other souls, the soul remains a substance in its own right, which does not require the body to complete its essence. On this showing, rather, soul and body are united accidentally. At death, consequently, the soul goes on being the substance that it is. ${ }^{16}$ By the same token, however, the body is a substance in its own right, which can exist independently of the soul, albeit not as a living body. This is because it too is comprised not only of matter but also its own specific 'form of corporeity', ${ }^{17}$ which in turn predisposes the body to be united to the soul.

This view is one early Franciscans found attractive because it allowed them to affirm that a dead body is in fact the body of the soul departed from it. Furthermore, it enabled them to account for the resurrection of the body, that is, the possibility of the body of a particular soul to be reconstituted at the end of time. In the years just before the Summa was composed, most notably in the work of Philip the Chancellor,

navim et secundum accidens movetur; ergo anima secundum substantiam dividitur a corpore, et, si movetur, secundum accidens movetur; ergo, anima est substantia praeter corpus.'

14 John of La Rochelle, Summa de anima, 51.

15 SH II, In4, Tr1, S1, Q2, Ti2, C1 (n. 328), Solutio, p. 399: 'Ad quod dicendum quod anima humana dicitur composita ex forma et materia intellectuali.'

16 Bernardo Carlos Bazàn, 'The Human Soul: Form and Substance? Thomas Aquinas' Critique of Eclectic Aristotelianism,' Archives d'histoire doctrinale et littéraire du Moyen Age 64 (1997): 104. For Avicenna, as Bazan writes, citing Avicenna's De anima 5.7, 'the relationship between soul and body ceases to have any meaning after death, once the goals that were sought with the union are achieved the soul continues to live its substantial self-sufficient existence in the company of the superior intelligences that are its true realm. The spiritual substance is the real self of a human being: we are our soul.'

17 Magdalena Bieniak, The Soul-Body Problem at Paris, ca. 1200-1250: Hugh of St. Cher and His Contemporaries (Leuven: Leuven University Press, 2010), 12. 
Avicenna's idea of an accidental relationship between the body and the soul, mediated by the form of corporeity, was a prevalent view at Paris. Although this view continued to be held in the next generation by the likes of William of Auvergne and others, the situation changed significantly with the early Dominican Hugh of St Cher, who ventured to insist that the body is in fact intrinsic to the substance of the soul, which exhibits the quality of unibilitas substantialis or unitability to the body. ${ }^{18}$

Although Hugh's Sentences Commentary represents an important turning point for this doctrine, its relatively early dating-between 1229 and 1231-left much room for development. Ironically, this happened more than anywhere in the hands of his later Franciscan contemporaries, above all, John and the authors of the Summa Halensis. As this suggests, there was not so much of the division between Franciscan and Dominican schools that would come to characterize the next generation of Bonaventure and Aquinas. Although Franciscans and Dominicans did differ on certain points in this period, there was more that they had in common as inheritors of a certain set of sources and questions than there was that divided them.

In the wake of Hugh, and in the work of John of La Rochelle particularly, the notion of unibilitas became the key feature that set the rational soul apart from the angel. While angels can be united to bodies in a merely instrumental sense, it is not natural for them to take a body. ${ }^{19}$ When they do so, consequently, it is not as a 'perfection to perfectible' as in the case of humans who are naturally inclined to the body, but merely as a 'motor to a moved', as Avicenna put it, or in Aristotle's terms, as a sailor to a ship that he navigates but does not obviously merge with in his essence. ${ }^{20}$ In consequence, angels cannot really be said to perform the bodily functions they might seem to perform. For example, they might appear to eat and digest food, but this is not necessary to keep them alive but only to show familiarity with beings that eat. ${ }^{21}$

Since their knowledge is purely intellectual, moreover, angels do not require the senses to know sense objects, even when they inhabit a body that has sense faculties. The reason that human beings possess both sense and intellectual faculties is precisely that they mediate between creatures and God, knowing one in relation to

18 Bieniak, The Soul-Body Problem at Paris, 26, on William of Auvergne, 33.

19 SH II, In2, Tr2, Q1, C5 (n. 112), Ad obiecta 7, p. 152: 'angelus (...) non sit unitus corpori sicut forma vel perfectio cum perfectibili'; cf. SH II, In2, Tr3, S2, Q2, Ti2, M2, C1, Ar1 (n. 183), 1, p. 238: 'Videtur quod angelus de natura sua sit substantia a corpore separata.'

20 SH II, In2, Tr3, S2, Q2, Ti2, M2, C1, Ar3 (n. 185), a, p. 240: 'Constat enim quod, quando spiritus angelicus assumit corpus, quod ei unitur; sed spiritus non videtur posse uniri corpori nisi aut sicut perfectio perfectibili aut sicut motor mobili: iis enim duobus modis unitur corpori; sed constat quod primo modo non unitur corpori; ergo secondo; et ita videtur quod pro tanto debeat dici quod angelus assumit corpus, quoniam unitur ei sicut motor mobili.'

21 SH II, In2, Tr3, S2, Q2, Ti2, M2, C2, Ar1-2 (nn. 191-2), pp. 245-6. Franklin T. Harkins, 'The Embodiment of Angels: A Debate in Mid-Thirteenth Century Theology,' Recherches de théologie et philosophie médiévales 78 (2011): 25-58. 
the other. ${ }^{22}$ Because angels only mediate between intellectual creatures and God, however, they do not need sense faculties by nature. The only reason they have them and the body more generally is that this is the sole means by which angels can imprint ideas on the human intellect, namely, by imprinting them on the senses, which are visual and auditory. ${ }^{23}$ Although angels therefore need a body in order to accomplish aspects of God's mission amongst human beings, they remain separate from the body even when they assume one. ${ }^{24}$

As we have established, this is not the case for humans, in whom the soul is naturally unitable to the body as its perfection. In support of this claim, John and the Summa like so many other contemporary texts cite Aristotle's De anima $2.1{ }^{25}$ At the time, this text circulated in a couple of main translations, namely, the GrecoLatin translation of James of Venice, which stated that 'the soul as the soul is the form', or elsewhere, the first act 'of the natural organic body having the potential for life' (anima est forma corporis physici organici potentia vitam habentis); and the Arabo-Latin translation of Michael Scotus, which reads that anima est prima perfectio corporis naturalis habentis vitam in potentia ('the soul is the first perfection of the natural body having life in potency'). ${ }^{26}$ At the time a number of variations circulated of the Scotus translation particularly, which was popular not least among John and the authors of the Summa Halensis, who invoke his definition explicitly. ${ }^{27}$

Although the difference between the translations might seem minimal, it was actually monumental. For to say that the soul is the 'form' of the body is to say that having a body is part of what it means to be a soul: ${ }^{28}$ that the soul cannot therefore exist without the body, and the body cannot be enlivened without the soul, which is precisely what the soul does as its 'first act'. ${ }^{29}$ This, ironically, is precisely what Aristotle's sailor/boatman analogy in De anima 2.1 is presumably meant to convey: not that the sailor and shipman are fundamentally separate entities as the Summa sug-

22 SH II, In2, Tr3, S2, Q2, Ti1, C2, Ar1 (n. 160), Solutio, p. 211.

23 SH II, In2, Tr3, S2, Q2, Ti2, M2, C1, Ar3 (n. 184), Respondeo 1, p. 240.

24 SH II, In2, Tr3, S2, Q2, Ti2, M2, C1, Ar3 (n. 184), Respondeo 1, p. 240: angels take on a body 'ad manifestationem ipsius creaturae spiritualis vel ad demonstrationem divinam ( ... ) quoniam angeli ad suum corpus non est unio sicut perfectionis ad suum perfectibile, sed sicut motoris ad mobile.'

25 Aristotle, De anima 2.1, 412a18-19.

26 Sander de Boer, The Science of the Soul: The Commentary Tradition on Aristotle's De anima, c. 1260-1360 (Leuven: Leuven University Press, 2017), 123. The slightly later Greco-Latin translation of William of Moerbeke read: 'anima est primus actus corporis physici potentia vitam habentis.' Daniel A. Callus, 'The Treatise of John Blund on the Soul,' in Autour d'Aristote: Recueil d'études de philosophie ancienne et médiévale offert à Monseigneur A. Mansion, ed. Auguste Mansion (Louvain: Publications universitaires de Louvain, 1955), 491, lists several variants of the definition that were used in the early $13^{\text {th }}$ century, all of which contain the term 'perfectio'.

27 SH II, In4, Tr1, S1, Q3, Ti2, C1, Ar1 (n. 344), Contra c, p. 418: 'anima est perfectio corporis physici, organici.'

28 Aristotle, De anima, 412a27.

29 Bieniak, The Soul-Body Problem at Paris, 13. 
gests, but that the soul activates the potential of the body to live in the way the sailor activates the potential of the ship to sail.

The reference to the soul as the perfection of the body, by contrast, represents the means by which Avicenna posited an independent existence for the soul, which comprises a separate substance from the body. ${ }^{30}$ For him, we have seen, the soul does not constitute the body qua body. This is the job of the form of corporeity; it only establishes the body as living. This incidentally is what is implied in Avicenna's idea of the soul as the 'motor' of what it moves, namely, that the soul is a sort of engine for the body that can keep on running even without it. The popularity of Avicenna's work during the period in question meant that his understanding of the body-soul relationship was preferred, whether scholastics referred to the soul as a form or as a perfection, or both. ${ }^{31}$

In his Summa de anima, John provides an excellent example of a thinker from this period who employs the terms 'form' and 'perfection' interchangeably. ${ }^{32}$ In most cases, he freely conflates the terms, for instance, when he affirms that 'the soul is united to the body as its form and perfection'. ${ }^{33}$ In another place, he says that the soul 'is united as form or as a perfection to a perfectible'. ${ }^{34}$ When he is explicating Aristotle's definition of the soul, however, he states that 'the soul is the perfection and form and first act of the body'. ${ }^{35}$ Similarly, the Summa Halensis refers to the soul not only as the form of the body, using Aristotle's term, but also employs the Avicennian terms not only of what is moved in relation to what moves it, or is perfectible in relation to that which perfects it. ${ }^{36}$ In fact the Summa conflates the terms, stating that a 'form is defined insofar as it perfects being, ${ }^{37}$

30 Bieniak, The Soul-Body Problem at Paris, 15.

31 Bieniak, The Soul-Body Problem at Paris, 17: 'The Arabic definition of the soul as perfection of the body enters the Latin West not only through Avicenna, but also thanks to Costa Ben Luca's treatise De differentia spiritus et animae. It is through the latter that the definition is assimilated into the first Latin work influenced by Avicenna, i.e. the De anima by Dominicus Gundissalinus.'

32 Bieniak, The Soul-Body Problem at Paris, 35: 'like Philip the Chancellor, John uses the terms "perfection" and "form" interchangeably.'

33 John Of La Rochelle, Summa de anima, 115: 'Item cum anima uniatur corpori ut forma et perfectio eius.'

34 John Of La Rochelle, Summa de anima, 116: 'respondeo: anima racionalis unitur corpori secundum duplicem modum: unitur enim ut forma sue materie sive ut perfectio suo perfectibili; unitur eciam ei ut suo organo sive instrumento per quod operatur duplex est ergo racio unionis. Secundum primum modum unitur anima corpori sine medio.'

35 John Of La Rochelle, Summa de anima, 58: 'anima sit perfectio et forma et actus corporis, est actus primus, non secundus.'

36 SH II, In4, Tr1, S1, Q3, Ti2, C1, Ar1 (n. 344), Ad obiecta 3, p. 419: 'corpus vero humanum indigent anima non tantum ut moveatur sed etiam ut in esse in quo est subsistat et permaneat, et ideo duplicem habet comparationem: ut mobilis ut motorem et perfectibilis ad perfectionem suam, unde unum in natura constituunt, scilicent hominem.'

37 SH II, In4, Tr1, S2, Q1, C2, Ar1 (n. 350), 1, p. 425: 'forma autem dicitur in quantum perficit esse.' 
As such examples illustrate, there is almost total fluidity in the use of terms that are technically contradictory. On this basis, scholars like Bazàn have accused early scholastics, including John, of exhibiting deep confusion about the true meaning of a form and the fact that it cannot, like a perfection, exist independently of the body. Of course, Franciscans avoided Avicenna's extreme dualism through the doctrine of unibilitas substantialis, which while defining body and soul as separate substances ultimately established them as one nature. ${ }^{38}$ However, Theodore Crowley concluded that they show no awareness of the 'metaphysical problems and indeed the contradiction inherent in simultaneously affirming that the soul is at once a form and an independent substance in its own right. ${ }^{, 39}$

As plausible as this criticism may seem at first glance, a further study of John's text and the Summa Halensis proves that early Franciscans were not ignorant of the deep differences between a form and a perfection. ${ }^{40}$ Their strategy for resolving the tension-which scholars like Bazàn and Crowley completely neglect to take into account-involves showing that in the exceptional case of the soul, there can be a form which by contrast to the norm can also be separable from matter. ${ }^{41}$ The detailed reasoning that underlies their claims in this regard lies beyond the scope of the current discussion.

At this point, I simply wish to summarize briefly the ground covered so far. The Summists transform Avicenna's description of the soul as the 'perfection' of the body into code language to describe their understanding of the soul as naturally and essentially unitable to a body. They also employ Avicenna's language that the soul serves as a motor to a moved, but since this analogy implies a fundamental dualism or separability of soul from body, it is not sufficient to capture the full way in which the soul relates to the body. This analogy does however serve adequately to describe the relationship, if any, that an angel may have to a body, that is, a purely instrumental or accidental one, which involves something like putting on a garment temporarily.

As we have seen, the substance dualism that underlies the Franciscan vision entered the theological scene in the years before the Franciscans, for example, in the work of Philip the Chancellor, whose Summa de bono probably dates to around 1230. This was still a period of some timidity with regard to embracing the full scale of philosophical sources such as Aristotle and Avicenna. Nevertheless, the pe-

38 SH II, In4, Tr1, S1, Q3, Ti2, C1, Ar1 (n. 344), Solutio, p. 418: 'coniungibilia sunt anima et corpus et uniuntur in unum ut fiat una natura.'

39 Theodore Crowley, Roger Bacon (Louvain: Éditions de l'Institut Supérior de Philosophie, 1950), 122: 'for these men, the soul was no less essentially form than it was substance (...) the metaphysical problems arising out of this combination may not have been clearly perceived.'

40 SH II, In4, Tr1, S1, Q3, Ti2, C1, Ar4 (n. 347), 1, p. 421: 'forma non habet esse praeter materiam; sed anima habet esse praeter corpus; ergo non dicuntur unum illo modo.'

41 SH II, In4, Tr1, S1, Q3, Ti2, C1, Ar4 (n. 347), Solutio, p. 422: 'haec unio, quae est animae et corporis, ( ... ) dicitur nativa et se habet ad modum formae cum materia.' 
riod does testify to a certain level of engagement, to the extent that this was perceived as compatible with the tradition of Augustine. Whether Augustine himself was a dualist along the lines of Avicenna is certainly up for debate. While it is a common opinion that he inherits dualistic tendencies from Platonism, the case for his dualism in the Middle Ages was made almost exclusively on the basis of spurious works like the De spiritu et anima and De fide ad Petrum, in the face of evidence that undermined the authenticity of such works.

The result was a reading of Augustine-not to mention Aristotle-which had more in common with Avicenna than any authentic idea of Aristotle or Augustine themselves. Such a tendency to read both figures in line with Avicenna was characteristic and indeed endemic for a period in which the Aristotelian and Platonic traditions were still fundamentally regarded as consistent and the distinctive features of Aristotle's thought were still not fully understood.

The confusion seeps into yet another area in which the Summa has noted that angels and humans differ, namely, regarding esse rationale, or the way they acquire knowledge, that is, discursively or not. This mode of being is closely related to the esse metaphysicum, whereby angels and rational souls are said to differ in terms of the way they receive data from the outside world. In order to see what is at stake in these differences, we must explore in more detail the early Franciscan psychology which deals with both matters at once. As I have hinted already, this is the main area in which John of La Rochelle in particular boldly breaks new ground that was never traveled by a theologian or thinker before him.

The interesting thing-and the one major structural difference-between the SDA and the $D A R$ is that the latter text changes the order in which it treats the main psychological schema that the author wants to consider. In the $S D A$, John deals first with Augustine, albeit the Augustine exclusively of the De spiritu et anima, then with Damascus, then with Avicenna by name. In the $D A R$, by contrast, the order is Aristotlewho was not mentioned in John's psychology at all-Augustine, and Damascus. This is one slight change that suggests perhaps a later date for the DAR; a growing awareness of Aristotle's authority as distinct from Avicenna's may have encouraged this reordering of priorities, even though it does not alter in any major way the actual substance of the views that the Franciscan authors want to present.

While these are presented partly in conversation with Augustine and Damascus, I am not going to discuss the way the Franciscan texts deal with these authors. Basically, such patristic authors make an appearance here because they are the main authorities in the Christian tradition to date who provided psychological schema, and as Dag Hasse has noted, Latin thinkers at this time were somewhat constrained to find a way to reconcile the new philosophical resources with their indigenous tradition. This tradition was in no way as sophisticated as Avicenna's when it came to describing the work of the senses and the intellect. In that sense, the patristic material is there basically to suggest or even to show that Christian thinkers provide a broad framework for thinking about human psychology into which Avicenna's account of the various faculties can justifiably be inserted. 
These thinkers for instance acknowledge the existence of three tiers of something like external and internal senses, as well as the intellect, even though they do not go much into the details of these faculties' operations. For this very reason, Hasse has noted, Latin thinkers at this time-and Rochelle above all-were inclined basically to adopt wholesale Avicenna's account of internal sensation, even while they looked for ways to reconcile his doctrine of the intellect with those that pre-existed in Augustine and Damascus.

In his $S D A$, John delineates quite straightforwardly an Avicennian account of the five internal senses. The common sense is that which receives forms imprinted by the five external senses and gives us a unified picture of their different aspects. What John calls the imagination retains those forms after they are no longer directly accessible by experience. The excogitative sense is able to compose and divide the different accidents attached to a given form. Estimation registers what is beneficial or harmful in the forms perceived, while the fifth internal sense of the memory apprehends and retains the product of estimation, that is, the intentions of sensible things, the images of things with their connotational attributes or positive or negative connotations.

Instead of detailing the way the DAR basically repeats this account of the internal senses, I will simply give its summary of their functions:

As regards sensible forms, there are faculties that apprehend, and those that preserve or transform. The first one apprehending the forms is called the common sense; the one preserving them the imagination or phantasia; the one transforming and comparing in the absence of matter is called the imaginative sense; the one that concerns intentions of good or evil or harmfulness or helpfulness, as a lamb with respect to a sheep or a wolf is either apprehending or preserving; if it is apprehending, it is called estimation, if preserving, memory. ${ }^{42}$

In transitioning from the discussion of the internal senses to the intellect in the $S D A$, John invokes a three-fold distinction between the passive or material intellect, which is necessarily united to the body, and then the separable intellect, which includes the possible and the agent intellects. This particular way of describing the intellects cannot be traced exactly to the available philosophical sources at the time-Aristotle, Avicenna, Alexander of Aphrodisias, and Averroes-but only to an anonymous theological text from around 1230 which construes their relationship in this way. ${ }^{43}$

42 SH II, In4, Tr1, S2, Q1, M2, C4, Ar2, (n. 361), I, p. 438: 'Quae vero est circa formas sensibiles aut est apprehendens aut custodiens aut transformans sive conferens absente materia. Si vero est apprehendens, dicitur sensus communis; si vero custodiens, dicitur imaginatio vel alio modo phantasia; si vero est transformans vel conferens absente materia, dicitur imaginativa. Si vero est circa intentiones, ut bonitatem et malitiam, sive nocumentum et iuvamentum, prout accidit de agno respectu ovis aut lupi, aut est apprehendens aut custodiens. Si apprehendens, dicitur aestimativa; si custodiens, dicitur memorativa.'

43 Daniel A. Callus, 'The Powers of the Soul: An Early Unpublished Text,' Recherches de théologie ancienne et médiévale 19 (1952): 131-70. 
According to John, the material intellect is what receives the forms or intelligible species in the phantasms; that is to say, it knows forms abstracted from matter in the mode of particulars. ${ }^{44}$ The possible and agent intellects know the forms abstracted from matter, as universals. The possible intellect does so only potentially: it is a tabula nuda ${ }^{45}$ or blank slate which is receptive to all kinds of forms but has none of them in act. The agent intellect is what makes the forms known, insofar as it is the source of an intelligible light of the first truth that is naturally impressed upon us.

In the first volume of the Summa Halensis, John goes into considerable detail as to what this light entails, developing his own version of Avicenna's doctrine of the transcendentals which are the 'first known' of all things. Following Avicenna, John says that 'being is the first object of the intellect'. In his account, however, being is qualified by three further concepts which respectively render the human mind an image of the Trinity. These include unity, which enables us to know one thing as distinct from another; truth, which renders a being intelligible as such; and goodness, which reveals the purpose of the being in question.

Thanks to these transcendentals or the image of God, the human mind has the conceptual resources to comprehend actual beings. It has a light by which to grasp whatever form may find itself in the possible intellect, which cannot itself render the forms it contains intelligible. When it comes to explaining how the agent and possible intellects work together, John invokes Avicenna's doctrine of the four intellects explicitly, along with his illustration of the stages in which a young boy learns to write. ${ }^{46}$

The first stage concerns the material intellect which has the capacity for all forms but is not yet subject to any form, as a young child has the capacity to learn to write before actually having learned to do so. The second is the intellect dispositionem habens or in habitu, which has the principles or skills needed to cognize forms before having done so. This is the stage at which the transcendentals would be acquired. The third is the intellectus perfectus or in effectum conclusionem, which has actually drawn conclusions from those principles but is not in the act of considering them at present. The fourth is the intellect in usu or 'in act'. This corresponds to the active intellect strictly speaking while the previous three correspond to the possible.

As previously suggested, the angels only have what could be described as the agent intellect and not the possible, because they exist separately from the senses of the body and do not need to receive data from them, which is then subject to the analysis of the agent intellect. The only sense in which they might be regarded

44 John Of La Rochelle, Summa de anima, 274.

45 John Of La Rochelle, Summa de anima, 275.

46 John Of La Rochelle, Summa de anima, 276. 
as possible is with respect to the forms of things they receive from God above, not through a discursive process, but directly or immediately. ${ }^{47}$

Whereas Avicenna had denied any intellectual memory of abstracted concepts, the Halensian Summists insist upon it, distinguishing between an innate memory, which holds the transcendental concepts, and acquired memory, which holds the concepts abstracted with the help of the transcendentals. ${ }^{48}$ On the matter of the active intellect, there is the further question that famously exercised Latin thinkers after Gundissalinus as to whether the agent intellect is in fact God in the case of human beings. In this regard, John invokes a distinction from the De spiritu et anima between things that are above, next to, and below the self.

In order to know what is above the self, namely, God, the mind needs God to act as Agent Intellect. In order to know what is next to the self, namely, angels, the mind needs angels to serve as the agent intellect. In order to know itself or inferior creatures, however, the aforementioned transcendentals are sufficient for human knowledge. This is a rather more conservative and perhaps plausible view than the one famously advocated by Roger Bacon, Roger Marston, and other Franciscans that God is the Agent Intellect in all respects. The Summa Halensis advocated the same position as John. ${ }^{49}$ It is not the case in the Summa, as in Avicenna and Gundissalinus, that the possible intellect alone belongs to the human.

Nevertheless, the Summa's account of the material, possible and agent intellects differs somewhat from that of John's original, not in its substance but in the fact that the substance is assigned to Aristotle rather than Avicenna, at least by the editors of

47 SH II, In4, Tr1, S2, Q3, Ti1, C2, Ar2 (n. 372), Ad obiecta 2, p. 452: 'Haec enim quae est in angelo, separata est a parte sensibili: unde non habet possibilem nisi dicatur possibilis, id est receptibilis illuminationum a Summo, sed habet partem sibi sufficientem ad cognoscendum ea quae nondum sunt cognita ab ea.'

48 SH II, In4, Tr1, S1, Q3, C5, Ar7 (n. 342), Respondeo, p. 415: 'Est memoria innata et acquisita. Memoria veritatis innata est principium intelligentiae et voluntatis: est enim, sicut dictum est, vis conservativa similitudinis primae veritatis impressae a creatione, et secundum hoc memoria attribuitur Patri, intelligentia Filio, voluntas Spiritui Sancto. Memoria vero acquisita primae veritatis potest considerari duobus modis, quia quantum ad fieri aut quantum ad esse. Quantum ad fieri naturaliter procedit acquisita memoria ex intellectu et voluntate: et secundum hoc intellectus, qui est generans veritatem, attribuitur Patri, voluntas, quae est genita, Filio, memoria, ex utroque procedens, Spiritui Sancto. Quantum ad esse vero, memoria veritatis acquisita potest esse principium veritatis intelligentiae et voluntatis' [The innate memory of the truth is the principle of understanding and will: for as is said, it is the power that conserves the likeness of the first truth that is impressed from creation. And in this way, memory is attributed to the Father, intelligence to the Son, and will to the Holy Spirit. The acquired memory of the first truth can be considered in two ways, insofar as it acts or insofar as it exists. Insofar as it acts, acquired memory naturally proceeds from the [operation] of the intellect and will. Thus, the intellect, which is what generates truth, is attributed to the Father, will, which is the cause of what is generated, to the Son, and memory, which proceeds from both, to the Holy Spirit. As regards its essence, the acquired memory of truth is the principle of truth of understanding and will].

49 SH II, In4, Tr1, S2, Q3, Ti1, C2, Ar2 (n. 372), III.2, p. 452. 
the text. Another notable difference is the absence of the doctrine of four intellects in this context. However, the Summist finds a way to affirm this still by concluding that Avicenna's signature doctrine is basically compatible with John of Damascus' account of the intellect, which of course bears no resemblance to it at all. This massive stretch of an argument goes to show just how hard early Franciscans would work to salvage the major aspects of Avicenna's psychology, even while trying to keep abreast of current trends by paying lip service to Aristotle and patristic authorities.

Further support for the argument that the Summists maintain an Avicennian rather than Aristotelian account of abstraction can be found in the Summa's account of the internal senses, which virtually pastes its content from John's $S D A$, which itself lifts almost verbatim from Avicenna's De anima. If we assume as Hasse and Alpina have argued that much of the work of abstraction takes place at the level of producing an intention by the internal senses, then it follows that the DAR presupposes Avicenna's idea of how the four intellects finish the job. ${ }^{50}$ So far as I can tell, there is no sign that the Summists understand the differences between Aristotle and Avicenna on abstraction, which are considerable but lie beyond the scope of the current paper.

In this connection, it is worth noting that the Summa Halensis constantly uses the term Philosophus interchangeably for both Aristotle and Avicenna, sometimes even exhibiting the cheeky tendency to pretend as if there was no difference between them, i.e. secundum autem Avicennam, qui sequitur Aristotelm ${ }^{51}$ or in attributing a quotation from Avicenna to Aristotle. All of this suggests that we are still in the phase spanning into the 1240s that Amos Bertolacci has described as one of 'reading Aristotle with Avicenna'. ${ }^{52}$ As noted, this was a time when interest in Aristotle was increasing, partly under the impetus of Averroes' recently translated commentaries, but the habit of reading Aristotle in terms of Avicenna was proving difficult to discard, and resources for doing otherwise were still thin on the ground.

What I have tried to do in this paper is give a taste of Avicenna's reception in the school of thought that interpreted him most enthusiastically and most faithfully in this period. Obviously, others of the generation most notably Albert the Great interacted with Avicenna extensively. But they seemingly did so in a slightly more sophisticated and sometimes even critical fashion. That is not to say that the Franciscan reception of Avicenna was altogether pure. As we have seen, it was mediated by the likes of Gundissalinus and mitigated by many others, such as Costa Ben Luca and Avicebron.

50 Tommaso Alpina, 'Intellectual Knowledge, Active Intellect, and Intellectual Memory in Avicenna's Kitab al-Nafs and Its Aristotelian Background,' Documenti e studi sulla tradizione filosofica medievale 25 (2014): 131-83.

51 SH I, P1, In1, T3, Q1, M1, C3 (n. 74), III, p. 119: 'Secundum autem Avicennam, qui sequitur Aristotelem ( ... ).'

52 Amos Bertolacci, 'On the Latin Reception of Avicenna's Metaphysics before Albertus Magnus: An Attempt at Periodization,' in The Arabic, Hebrew and Latin Reception of Avicenna's Metaphysics, ed. Dag Nikolaus Hasse and Amos Bertolacci (Berlin: De Gruyter, 2012), 197-223, esp. 204. 
Above all, it was undertaken in many cases under the guise of reading Aristotle and Augustine, although we have seen that the operative understanding of both authors was somewhat distorted not least by the wide circulation of spurious texts. That is not to say that the Franciscan philosophy of the soul was confused. Notwithstanding the liberties taken with Aristotle's idea of the soul as the form of the body, and just about every idea that could be linked to Augustine, the Franciscans of the early scholastic period, and John first and foremost, knew what they thought about human psychology. And the ideas they developed would continue to form Franciscan ideas on this subject for generations, long after the links to Avicenna or anyone else had been forgotten. 
